UDC 37.013.42:323.1]:364-43

DOI https://doi.org/10.24919/2308-4863/38-3-22

Yuliia RIABOVA, orcid.org/0000-0002-0608-6293

Candidate of Pedagogical Sciences, Senior Teacher at the English Language Department Petro Mohyla Black Sea National University (Mykolaiv,Ukraine) r.yuliasha04@gmail.com

\title{
PROFESSIONAL TRAINING OF FUTURE SPECIALISTS IN SOCIAL SPHERE IN THE CONDITIONS OF MULTICULTURAL SOCIETY
}

The article is devoted to the problem of professional training of future specialists in a multicultural society. The author analyzes researches and publications on this topic. The author notes that in the era of globalization, when the separate existence of different people and cultures becomes impossible, when there is a question of combining national values, there is a rethinking of goals and objectives of education and it becomes clear that the current content of education does not sufficiently fulfil the needs of society. New paradigms of education are discussed, and such concepts as multicultural education, culturological approach and intercultural competence are used. According to the National Doctrine of Education Development of Ukraine, the main goal of education is to form a high culture of interethnic relations of future specialist who is ready to intercultural interaction. The multinational society is an integral feature of the modern developing world. The growing awareness of the increasing social confrontation in the world between the growing level of the multinational society where people live and work, and their unpreparedness for these changes have led to the need for proper training. Today, it is important to establish positive relations between people in a multinational society. Professional training is defined as a system of organizational and pedagogical activities. It ensures the formation of a person's professional orientation, knowledge, skills, abilities and readiness for professional activity. Intercultural competence is the ability to recognize, respect and effectively use differences in the perception, thinking and behaviour both in your own culture and foreign culture. The formation of intercultural competence in the process of training for professional activity in a multinational society presupposes readiness to interact with other systems of cultural orientation and is based on respect other cultural values.

Key words: professional training, multicultural society, university education, intercultural competence, professional activity, future specialists.

Юлія РЯБОВА, orcid.org/0000-0002-0608-6293 кандидат педагогічних наук, стариий викладач кафедри англійської мови Чорноморського національного університету імені Петра Могили (Миколаїв, Україна) r.yuliasha04@gmail.com

\section{ПРОФЕСІЙНА ПІДГОТОВКА МАЙБУТНІХ ФАХІВЦІВ СОЩІАЛЬНОЇ СФЕРИ В УМОВАХ МУЛЬТИКУЛЬТУРНОГО СЕРЕДОВИЩА}

Статтю присвячено проблемі професійної підготовки майбутніх фахівців в умовах мультикультурного середовища. Автором проаналізовано дослідження і публікаиї з такої теми. Автор зазначає, шо в епоху глобалізації, коли відокремлене існування різних народів і культур стає неможливим, коли стоїть питання про поєднання наиіональних иінностей, іде переосмислення иілей $i$ завдань освіти і стає зрозуміло, цо діючий зміст освіти не задовольняє достатньою мірою потреб сочіуму, виникають $і$ широко обговорюються нові парадигми освіти, і все частіше вживаються такі поняття, як полікультурна освіта, культурологічний підхід, міжкультурна компетенція. Мета статті - проаналізувати та визначити головні аспекти підготовки майбутніх фахівців соиіальної сфери в мультикультурному середовищі. Автор зазначає, щчо багатонаціональність простору життєдіяльності людини - ие невід 'ємна риса сучасного розвиненого світу. Зростаюче усвідомлення світового громадського наростаючого протистояння між підвищенням рівня багатонаціональності соиіального середовища, в якому живе і працює людина, ї̈ непідготовленістю до цих змін, призвело до того, щчо необхідною стає належна підготовка фахівиів до професійної діяльності в багатоначіональному середовищі. Нині важливо встановити позитивні стосунки між людьми в багатоначіональному суспільстві. Професійна підготовка визначається як система організаційно-педагогічної діяльності. Це забезпечує формування у людини професійної орієнтації, знань, умінь, навичок та готовності до професійної діяльності. Міжкультурна компетентність - ие здатність розпізнавати, поважати та ефективно використовувати відмінності у сприйнятті, мисленні та поведінці як у власній культурі, так і в чужій культурі. Формування міжкультурної компетентності в прочесі підготовки до професійної діяльності в багатонаціональному суспільстві передбачає готовність до взаємодї з іншими системами культурної орієнтації та базується на повазі інших культурних ичінностей.

Ключові слова: професійна підготовка, мультикультурне середовище, університетська освіта, міжкультурна компетентність, професійна діяльність. 
Introduction. The development of Ukrainian society is characterized by intensive social, economical and geopolitical changes that give rise to political, economic, social and psychological problems. According to the National Doctrine of Education Development of Ukraine, the main purpose of education is to form a high culture of interethnic relations. Prerequisite for the establishment of a developed society is the training of educated, moral, mobile people who capable to cooperate and interact in multinational society. Today it is important for Ukrainian society to establish positive relations between people in a multinational society, prevent interethnic conflicts, form the future students' culture of communication, ethnic and tolerance.

The necessity to create a new generation of future professionals capable to professional activity in a multinational society is a priority of pedagogical education and was reflected in the state documents and laws of Ukraine. The success of the future specialist in a multinational society is associated with the formation of his skills to regulate intercultural relations, provide conditions for personal development and use socio-cultural knowledge and communication skills in communication with people of different nationalities and social groups.

Analysis of relevant research. The works of V. Andrushchenko, M. Yevtukh, I. Zyazyun, V. Kremen, V. Lutay, S. Sysoeva, etc. are devoted to the problems of preparation of qualified specialists for the professional activity. The issues of training specialists to the professional activity in a multicultural society are reflected in the works of R. Agadulin, J. Guletska, O. Gurenko, E. Nechaeva and others. The works of E. Bystrytsky, O. Hryva, M. Sherman and others are devoted to the problems of development of tolerance in a multicultural society.

Aim of the study. The aim of the article is to analyze and identify the main aspects of training of the future professionals in the social sphere in a multicultural society.

Research Methods. Theoretical research methods were used to obtain the main goal of the article such as study and analysis of scientific and methodological literature to substantiate the main theoretical issues of the topic. During the years of state independence of Ukraine, the direction of internal and external migration flows have undergone significant changes and acquired new significance. Migration is an important factor in social development and it is related to economic, political, ethical and religious factors. By influencing the economy, population and other social systems, migration contributes to their effective functioning. Migration is a common phenomenon in the world, and Ukraine is no exception.
In Ukraine, there are legislative acts that ensure the implementation of state ethno-national policy. Declaration of the Rights of Nationalities of Ukraine according to which the Ukrainian state guarantees representatives of different nationalities who are living in its territory equal social, political, economic and cultural rights, the right to use their native language, the right to practice their religion, the right to establish their cultural centres, museums and communities. Law of Ukraine according to which the state guarantees all representatives of other nationalities (national minorities) the right to national and cultural autonomy and the development of national cultural traditions. The state takes measures for training through a network of educational institutions. The Law of Ukraine "On Education" which states that foreigners and persons recognized as refugees have the same right to education as the citizens of Ukraine. "On Freedom of Conscience and Religious Organizations" under this law does not allow any coercion in determining a citizen's attitude to religion, and restriction of rights, establishing direct or indirect preferences of citizens depending on their attitude to religion. The Law of Ukraine "On Refugees", "On the Legal Status of Foreigners", Framework Convention for the Protection of National Minorities, European Charter for Regional or Minority Languages, other normative legal acts and international treaties approved by the Verkhovna Rada of Ukraine and European standards on the issues of preserving the cultural identity and identity of people of different nationalities.

However, the issues of development and protection of representatives of different nationalities (national minorities) who are living on the territory of Ukraine are not always properly implemented. According to the law of Ukraine "On the concept of state ethno-national policy", the principle of state ethnopolitics should take into account the existing positive experience in Ukraine in resolving national issues and the need to develop this area of relations taking into account the following features: recognition of the multiethnicity and multiculturalism of Ukrainian society and its social value, which needs protection and preservation; a combination of state support for the needs of different national communities and the creation of conditions for their free, independent and organic development; the equality before the law of all citizens, regardless of their cultural and national characteristics.

In the era of globalization, when the separate existence of different people and cultures becomes impossible, when there is a question of combining national values, there is a rethinking of the goals and objectives of education and it becomes clear that the 
current content of education does not sufficiently meet the needs of society. The new paradigms of education are emerging and widely discussed, and concepts such as multicultural education, culturological approach, and intercultural competence are increasingly used.

The multinationality of the space of human life is an integral feature of the modern developed world. The growing awareness of the world's public confrontation between the increasing level of multinational social society in which people live and work, and its unpreparedness for these changes has led to the need for proper training for professional activity in a multinational society.

UNESCO documents formulated a global concept of education, the purpose of which is to ensure the prevalence of values and ideals of a culture of peace, tolerance, active intercultural communication and the development of international cooperation in the future society.

The following stages of professional training are distinguished in Ukraine: professional training, which is carried out in general educational institutions: schools, lyceums, gymnasiums, technical schools; in institutions of additional education: houses of children's creativity, social and pedagogical clubs, in higher educational institutions: faculties of the future social pedagogue, full-time and part-time schools. After graduating from the university, specialists, depending on the degree of professional training of bachelors or masters, have the right to engage in professional and practical, educational, pedagogical or research work. Higher vocational education can be obtained on the basis of complete general or secondary vocational education (Bhawuk, Brislin, 1992).

Professional training is defined as a system of organizational and pedagogical activities that ensures the formation of a person's professional orientation of knowledge, skills, abilities and professional readiness for professional activities and is carried out in the framework of training in pedagogical universities, colleges and faculties (Ozhehov, 2007).

Professional readiness of a student is a personal quality that is manifested in a positive self-esteem as a subject of future professional activity and the desire to engage in it after graduation. It helps a young specialist to successfully implement professional functions, properly use the acquired knowledge and experience, maintain self-control and overcome unforeseen obstacles. Professional readiness is a crucial condition for a rapid adaptation of the graduate to working conditions, his further professional development and training (Druzhinin, 2003).

Thus, today in foreign and domestic social and psychological sciences there are such concepts associated with the designation of competence required in cooperation with representatives of different nationalities: intercultural competence, cross-cultural competence, cultural competence, multicultural competence, intercultural sensitivity, intercultural communication competence.

The terms "intercultural competence" and "intercultural communicative competence" most often refer to the skills and abilities to productively build intercultural business and personal relationships with people of different nationalities.

Thus, according to A. Karnyshev, E. Hall, the concepts of "intercultural competence" and "intercultural communicative competence" are connected. Under the first A. Karnyshev understands as a set of social skills and abilities with which the individual successfully communicates with a partner of another nationality in both professional and domestic contexts. The second concept is interpreted as the ability to effectively communicate with a partner of another nationality, taking into account ethnopsychological abilities (Karnyshev, 2014). Thus, intercultural communicative competence is considered as one of the main components of intercultural competence in the context of professional activity in a multinational society.

According to E. Hall, the structure of intercultural communicative competence includes intercultural sensitivity and tolerance for differences in culture, as well as in the historical heritage of groups involved in the interaction. D. Bavuk and R. Brislin consider intercultural sensitivity as an individual's reaction to cultural differences and the specifics of perception of people of other nationalities. Intercultural competence of the individual is interrelated with psycho physiological properties, the orientation of the individual to a positive outcome of communication, relevant abilities, knowledge and skills, self-esteem and communicative qualities (Bhawuk, Brislin, 1992). The most famous approach to the development and formation of intercultural competence is the model of M. Bennett. In accordance with this concept, intercultural competence is formed depending on the complexity and diversity of the experience of intercultural differences. The process of formation of intercultural competence is presented by M. Bennett in the form of a sequence of stages: the transition from ethnocentrism to ethnorelativism (Bennett, 2001).

Ethnocentric strategies are based on the fact that the individual views his culture as central, while ethnically relevant strategies mean that the individual experiences his culture in the context of other cultures. Ethnocentric strategies include three stages: denial, protection, and minimization. At the stage of denial, 
individuals perceive their culture as the only existing one, other cultures are either not noticed or understood in a simplified way. The individual is not interested in cultural differences. At the stage of protection, your own culture is considered the best, which can be the basis for negative stereotypes. Personality can be aggressive and afraid of differences. At the stage of minimization, a person recognizes differences in habits: food, customs, but recognizes the similarity of physiological, psychological and universal values.

Discussing the experience of other countries. For instance, there are currently three educational models in the United States to prepare students for multinational activities. The first model provides for the inclusion in the curriculum of training courses, the content of which includes the study of the history of national minorities, racist attitudes, communicating techniques and takes into account cultural differences of different nationalities who live in the same area.

The second model is based on the approach according to which the formation of intercultural competence is impossible within one or two disciplines. Therefore, the training includes such disciplines as sociology, anthropology, linguistics and a number of other disciplines related to the study of different nationalities. An integrative approach involves the formation of multicultural competence not within certain courses, but within all the courses that are studied. This approach is the most complex, as it requires the integration of the efforts of the entire teaching staff.

The professional training of future specialists in the conditions of multicultural society implies the formation of intercultural competence. Consider the structure of intercultural competence. V. Gudykunst proposed a model of intercultural competence, which consists of three main components: motivational factors, knowledge factors and skills factors. The first component involves the needs of the participants and their mutual attraction, social ties, self-awareness and openness to new information. Factors of knowledge consist of expectations, common information networks, ideas about more than one point of view, knowledge of alternative interpretations and knowledge of similarities and differences. The third component includes the ability to show empathy, be tolerant to other nationalities, adapt communication, create new categories, modify behaviour and gather the necessary information.

J. Lehtonen considers the approach of many authors to intercultural competence as tolerance to the manifestation of cultural peculiarities, cultural sensitivity to the rules of behaviour in a particular culture, awareness of certain cultural facts to be somewhat limited (Lehtonen, 2003). For successful communication in another culture, from the point of view of the author, it is necessary to know the language, history of the country, art, economy, society, to have a comprehensive knowledge of the culture of this country.

Based on the analysis of the works of foreign and domestic researchers on the essence of intercultural competence, we conclude that to achieve effective intercultural communication, knowledge and skills are necessary components, but not exhaustive. The formation of intercultural competence in the process of training for professional activity in a multinational society presupposes readiness to interact with other systems of cultural orientation and is based on respect for other cultural values. Intercultural competence is the ability to recognize, respect and use different qualities in sprinting, mixing and behaviour of people and other cultures in carrying out professional activities in a multinational society.

Therefore, in our review, the main features and components of the structure of intercultural competence in the training of future specialists of social sphere in the conditions of a multinational society should be:

- openness to knowledge of another's culture;

- ability to perceive intercultural differences;

- awareness of the importance of cultural differences;

- ability to overcome misunderstandings that arise in the process of intercultural interaction;

- willingness to cooperate with representatives of different nationalities;

- ability to acquire knowledge about other cultural realities and use them;

- curiosity and openness towards representatives of different nationalities;

- ability to overcome social, national and cultural stereotypes;

- ability to easily adapt to a new socio-cultural environment.

Conclusions and prospects for further research. As part of the training of social workers abroad, the content of multicultural competence is revealed through cognitive, emotional and behavioural components. Multicultural competence involves the mastery of the following competencies: awareness (reflection) of their own beliefs in relation to the diversity of nationalities of clients; knowledge of different cultures and the ability to use skills and technologies adequate to the national characteristics of the client. Thus, knowledge and skills in the context of preparing students for professional activities should be combined with openness, flexibility of their own thinking, as well as a motivated desire to carry out effective professional activities and 
successfully build relationships. The formation of intercultural competence in the process of preparation for professional activity in a multinational society presupposes readiness to interact with other systems of cultural orientation and is based on respect for other cultural values. Intercultural competence is the ability to recognize, respect and effectively use differences in the perception, thinking and behaviour of our own and another culture in carrying out professional activities in a multinational society.

\section{BIBLIOGRAPHY}

1. Гришкова Р. О. Інтернаціоналізація освіти з позицій компетентнісного підходу до навчання. Стратегї краӥн Причорноморського регіону в геополітичному просторі. Миколаїв, 2015. С. 24-29.

2. Позняк О. В. Міграційні процеси в контексті демографічного розвитку України: сучасний стан і перспективні тенденції. Економічний часопис XXI. 2002. С. 34-43.

3. Поликультурное образование: теоретико-методические аспекты : коллективная монография / под ред. М. В. Филатова. Тула : Изд-во ТГПУ им. Л. Н. Толстого, 2011. 109 с.

4. Садохин А. П. Межкультурная компетентность: понятие, структура, пути формирования. Журнал социологии и соииальной антропологии. Том Х. № 1. 2007. С. 125-139.

5. Чубук Р. В. Професійна підготовка соціальних працівників з використанням методу проєктів. Актуальні проблеми державного управління, педагогіки та психології. Вип. 1. 2014. С. 181-185.

6. Bhawuk D. P. S., Brislin R. The measurement of intercultural sensitivity using the concepts of individualism and collectivism. International Journal of Intercultural Relations. 1992. No. 16. P. 413-436.

7. Bennett M. J. A developmental approach to training intercultural sensitivity. / In J. Martin (Guest Ed.), Special Issue on Intercultural Training. International J. of Intercultural Relations. 1986. Vol. 10, No. 2. P. 179-186.

\section{REFERENCES}

1. Hryshkova R. O. Internatsionalizatsiya osvity $\mathrm{z}$ pozytsiy kompetentnisnoho pidkhodu do navchannya [Internationalization of education from the standpoint of a competency-based approach to learning]. Strategies of the Black Sea region in the geopolitical space. Mykolaiv, 2015, pp. 24-29 [in Ukrainian].

2. Poznyak O. V. (2002). Mihratsiyni protsesy v konteksti demohrafichnoho rozvytku Ukrayiny: suchasnyy stan i perspektyvni tendentsiyi [Migration processes in the context of demographic development of Ukraine: current status and future trends]. Economic Journal XXI. Pp. 34-43 [in Ukrainian].

3. Polikul'turnoye obrazovaniye: teoretiko-metodologicheskiye aspekty: kollektivnaya monografiya [Multicultural education: theoretical and methodological aspects: a collective monograph]. Tula: Izd-vo TSPU im. L. N. Tolstoy, 2011. 109 p. [in Russian].

4. Sadokhyn A. P. (2007). Mezhkulturnaya kompetentnost: ponyatiye, struktura, puti formirovaniya [Intercultural competence: concept, structure, ways of formation]. Journal of Sociology and Social Anthropology. Tom X. No. 1. Pp. 125-139 [in Russian].

5. Chubuk R. V. (2014). Profesiyna pidhotovka sotsial'nykh pratsivnykiv za metodom proektiv [Professional training of social workers by the method of projects]. Actual problems of public administration, pedagogy and psychology. Vip. 1 . P. 181-185 [in Ukrainian].

6. Bhawuk D. P. S., Brislin R. (1992). The measurement of intercultural sensitivity using the concepts of individualism and collectivism. International Journal of Intercultural Relations. No. 16. Pp. 413-436.

7. Bennett M. J. (2001). A developmental approach to training intercultural sensitivity. Special Issue on Intercultural Training. International J. of Intercultural Relations. Vol. 10, No. 2. Pp. 179-186. 